\title{
A Journey Through Global Bioethics
}

\author{
Kristina Orfali
}

Published online: 6 September 2019

(C) Journal of Bioethical Inquiry Pty Ltd. 2019

This issue of the Journal of Bioethical Inquiry $(J B I)$, dedicated to a cross-cultural symposium gathering articles from different countries, is fully consistent with the journal's mission. JBI is not just an academic journal; it aims at fostering a community of bioethics scholars and practitioners from multiple disciplines and all corners of the world.

The four papers included in this volume represent three different and contrasted geographical areas: the Middle East, Latin America and South Asia (specifically the Malayan Archipelago). The bioethical literature from the Middle East remains quite scarce, although a few countries (particularly Jordan) have recently attracted more attention. Latin American voices are not often heard in the field of bioethics, and mostly in papers published in Spanish; and the theoretical analysis on Islam Bioethics in the context of the Malayan Archipelago can be seen as unique. As such, these "unheard voices" are particularly welcome to participate in the dialogue fostered by a cross-cultural perspective within the bioethics community.

Cross-cultural bioethics (Myser, 2011) is an expanding field. North American bioethics have been largely exported in both western and developing countries. A large literature has analyzed how this North American model, with its prevailing autonomy paradigm, may in some cases collide

K. Orfali $(\bowtie)$

Department of Pediatrics, Division of Neonatology, Columbia Medical Center, Columbia University, New York, NY, USA

e-mail: ko2145@cumc.columbia.edu with local ethical systems and values. The critique has shifted to a more creative stance with attempts to introduce alternatives to the by now dominant vision. Even within the so-called "western bioethics", numerous contributions offer a (mostly European) critique of the prevalence of the autonomy principle, and support alternative notions - such as dignity (Feuillet-Liger and Orfali 2018), solidarity or justice - as core values. According to Mills (2010), "continental bioethics" criticize Anglo-American bioethics on the grounds that it "presuppose the model of the liberal individual as an accurate account of moral agents, thereby emphasizing correlative concepts such as interests, rights and freedoms, without due consideration of the relational contexts that agents always operate within." The discussion has evolved beyond the sole context of "Westernized" societies. Several papers (for instance Metz, 2012) have presented an Africanist perspective, rooted in "Ubuntu", as offering an alternative perspective to the "principlism" (Beauchamp et al.) that characterizes the North American approach. Attempts to shape an Islamic approach to bioethics have fostered a vivid discussion between scholars discussion of which Ibrahim et al.'s work and Padela's response in this issue provide an illuminating example.

The present volume belongs to the same spirit. Heterogeneous as they may appear to be, the papers presented here all aim at finding a balance between the principle of autonomy and other principles more attuned to the local cultures of each context. They all emphasize a greater role of family and community in ethical decision making. And while they all take American bioethics as a benchmark, they all try to dissociate themselves from it, at least to some extent, by proposing alternative 
models. The context, values and culture in which bioethics develop and are reframed and transformed are central to a cross-cultural exploration. Despite a growing literature, there is still a lack of overall knowledge regarding these issues - due to language barriers (bioethics has still a low academic impact in Latin America for example), to difficulties in apprehending internal reasoning and thinking, particularly in non-western societies (Ibrahim et al. 2019; Padela, 2019), and to the lack of empirical work (Obeidat \& Komesaroff., 2019). This volume attempts to provide some insights regarding these issues.

The paper by Garcia et al. 2019 presents a narrative review of the history of bioethics in Latin America. While Latin American countries share many common historical and social features with the "West" - from the (neo-)colonial Spanish or Portuguese influence to the social and political impact of the Catholic Church - bioethics emerged lately as a distinctive field; most published work come from Brazil, Colombia and Chili. The authors offer a review of the scientific output in the field of bioethics and of the main topics discussed, such as: the beginning and end of life (status of embryo, abortion, end of life/ palliative care as a human right); research ethics; doctor-patient relationship and ethical training. Though the main standard references reported in the review are "principlism theory" and a human rights based approach, Latin America has although infrequently - introduced alternative models, such as complex (or complexity) bioethics, intervention bioethics or protection bioethics. Complex bioethics draw from the work of the French sociologist Edgar Morin and other scholars; it is "an integrative alternative using several theoretical references, borrowing from principlism, virtue ethics and human rights". Intervention bioethics (Garrafa and Porto 2003) is a critique of the individualistic framework of the American bioethics which does not focus on public healthcare issues; it aims at introducing a political analysis of moral conflicts, with a greater attention to social inequalities and power relationships. Bioethics cannot in this perspective be dissociated from the persistent issues of poverty and inequality: what is the point of dealing with ethical clinical issues in the hospital without considering the dramatic issue of non-access to healthcare (Dos Anjos, 1999)? In this perspective, bioethical questioning has to start within the messy social reality. The third model, protection bioethics, concentrates on the so-called vulnerable populations and is understood "as an applied ethics constituted of theoretical and practical tools aimed at understanding, describing and resolving conflicts of interest between those who have the means that enable them to fulfill their lives and those who do not"'Schramm 2008). Though this last perspective remains secular, one cannot help seeing an inspiration reminiscent of the Latin America theology of liberation.

Finally, and despite the weak academic influence of bioethics in Latin America pointed out by the authors, the Latin American bioethical framework does not give to the autonomy principle the dominant role it has acquired in the US. Non-commercialization and inviolability of the body are core values of Latin America's bioethics, and are constraining the freedom inherent to autonomy. Two bioethical and legal frameworks are here in stark opposition. One holds human dignity as a core principle (as explicitly expressed in the constitution of several Latin American countries (Crespo-Brauner 2018; Dominguez-Hidalgo, 2016); the other tradition holds an individual's freedom and autonomy to be the governing principle, at least insofar as it does not entail harm to someone else.

The theoretical work by Ibrahim et al. 2019 introduces Maqasid al-shariah-based Islamic bioethics, which uses the objectives of the Shariah to address bioethical issues. In an area of evolving technology and development of science, the authors want to analyze how the Shariah can provide adequate responses. A crucial issue is whether the various technological innovations involved comply with Islamic teachings. The authors propose the notion of "Maqasid- al-sharia", defined as a morality system based on Islam that combines two disciplines of knowledge. One is provided by biological science; the other is a human value system in which assessments are based on the objective, purpose or ultimate aim of every Shariah of Islam. Maqasid al-Shariah protects the interests of mankind, but these interests are defined by Islamic teaching (and not individual desire). The authors discuss how these notions can guide decisions in different cases, particularly by establishing a hierarchy between different imperatives. In Maqasid al-Shariah-based Islamic bioethics, issues are viewed from the perspective of the collectivity, rather than the individuals; family and community bonds are crucial.

There is a general trend among Islamic scholars toward the "Islamization" of bioethics (Hassan, 2018). For example, the secular Universal Declaration of $\mathrm{Hu}-$ man Rights (UDHR) of 1948 was reshaped as the Universal Islamic ${ }^{1}$ Declaration of Human Rights in 1981 (and again in 1990), emphasizing the fact that ethics

\footnotetext{
$\overline{1}$ Obviously, the opposition between "universal" and "Islamic" de facto negates the universality that underpins the UDHR!
} 
cannot be dissociated from religion, particularly in Islamic countries. In fact, as pointed out by Guiderdoni $(2001)^{2}$, "the Arab adjective akhlâqî, which translates into 'ethical', is linked to the root Khalaqa which refers to God's creation". The work of Ibrahim and his colleagues belongs to this trend (as illustrated for instance by Abdelhalim, 1998 or Mokhtar Al-Hkadmy, 2001, 2002); new technologies - cloning, genetics or the human genome - are considered within the framework of the Sharia. In the context of Islamic bioethics, it is a conceptual approach that combines religion, ethics, and law. Crucially, these three aspects (religion, ethics, and law) are commonly duty-oriented. As a matter of fact, Islam views religion, ethics, and law as one entity; hence each moral action is legal in the eyes of Islam and vice versa. Islamic bioethics outlines that a person needs to consider the interests and rights of others around him/ her to preserve the stability and harmony of the community. Therefore, in coming to a medical decision, a discussion between close relatives is important and the decision must be made in agreement with the family.

A western reader might feel somewhat uneasy at Ibrahim et al.'s text describing the "real" Maqasid- alsharia - as opposed to its softer and westernized version. Yet, it seems important to understand what Islamic scholars in different countries mean; and how, in fact, fulfilling the interests and satisfaction of individuals cannot, according to the original teachings of Islam, be a society's ultimate goal. In the holistic context described by Ibrahim et al., the notion of individual remains weak; we need to put aside our westernized biases to grasp the way Islamic scholars deal with the new technologies in a manner that is totally foreign to us.

That said, we must also carefully avoid considering this model as the Islamic model of reference; it remains of course speculative at best, given the huge diversity of countries where Islam is the dominant religion, even within the Sunni Muslim world (Aouij-Mrad, 2018). The critical commentary by Padela (2019) rightly points out that "multiple Islamic authorities have developed different maqāșid al-Sharīah formulae"; which one should serve as the moral end-goals for an Islamic bioethics, and how to incorporate modern biomedical science into this concept, is far from obvious. The author

\footnotetext{
$\overline{{ }^{2} \text { Guiderdoni, A. }}$ 2001. Les principes fondateurs de l'éthique en islam. Revue d'éthique et de théologie morale, Le Supplément, n2017, juillet 2001 :88. Translated from French, «l'adjectif arabe akhlâqî, qui entend correspondre à l'adjectif éthique, a déjà une toute autre consonance car, par sa racine Khalaqa, il se réfère à l'idée de création par Dieu ».
}

explores three potential responses; "surface-level theorization, conceptual extension and a text-based postulation". The author goes on identifying practical gaps and even contradictions in Ibrahim et al.'s approach, criticizing the proposed hierarchy of which interests to prioritize. How should we evaluate a technology preserving one interest but harming another one? It might be different in different countries according to priorities and interests. In the end, it is the mere notion of a uniform Islamic bioethics that is under debate.

In practice, as demonstrated by the more empirical paper by Obeidat et al., 2019 health professionals in the Arab and Islamic world are often struggling between the conservative teachings of Islam and the western values of clinical ethics. Many doctors and even managers in Jordan have been trained in the West and experience first-hand the tensions between the needs of the individual patient and the cultural and religious imperatives of their tradition. The survey presented here describes the challenges and dilemmas faced by health professionals in an area that is so quickly evolving. Three binary areas of contention among physicians are pointed out by the survey: "conservatism/pragmatism" (as applied to decision-making), "traditional/modern" (Arab, Islamic and tribal values versus imported, western ethical ones) and "religion/secularism". This last area of tension is particularly vivid; while there is a growing social pressure to disengage ethical decision-making from religious authorities, there is at the same time (as expressed in the previous articles) a recurrent and stark opposition advocating an explicit and strict reference to Islamic teachings (or religious authorities) when it comes to ethical decision-making. The obvious lack of consensus regarding clinical ethics reflects the macro-level issue of globalization in a society affected by new critical attitudes and the questioning of traditional values, particularly among younger generations in the region. While some welcome syncretism, others seek a stricter adherence to religious principles. The tension and lack of consensus described in this paper can be viewed as symptomatic of a more democratic society - while it is tempting to relate the obsession with unity and holism to a more authoritarian perspective.

These four articles, despite their different contexts, emphasize the cultural worlds of bioethics. It was once assumed that there was only one correct ethical point of view; it is now necessary to recognize a proliferation of value systems, including different visions of freedom, happiness and the common good. Interestingly, three of 
these papers position themselves with respect to the North American model of bioethics ("principlism"), criticizing its difficult application to their local world. The North American model does not respond to the dilemmas of social inequalities and poverty so crucial in Latin America; it does not take into account the overwhelming religious background in Islamic countries. Bioethics was a latecomer in all three areas considered here. While these contributions all emphasize the importance of community (sometimes even over the individual), and while they speak to justice and equality more than autonomy, they balance more or less between the western notion of the individual and a more holistic approach of traditional societies.

Cross cultural ethics cannot escape the debate of moral relativism versus universalism. Though these papers give an account of societies which do not necessarily share the same moral conceptions of human welfare, harm, justice, autonomy, and other core values espoused in North American bioethics, the fact that all regard "principlism", and particularly autonomy, as the key benchmark against which they position themselves implies that this reference remains after all, if only implicitly, a quite universal value.

\section{References}

Abdelhalim, R. 1998. La protection juridique de génome humain. Le Caire, Dar al-Nahda al-Arabia.

Al-Hkadmy, N.M. 2001. Le clonage à la lumière des principes, règles et buts de la Shari'a. Dar al-Zahmm, al-Ryad.

Al-Hkadmy, N.M. 2002. L'ingénierie génétique à la lumière de la Shari'a musulmane, Majallat al-Bouhous al-fiqhia almo'assira, al-Ryad, n52, année 13, 2002.

Aouij-Mrad, A. 2018. The Principle of Human Dignity in Tunisia: Between Political Recuperation and Low Practical Recognition. In The Reality of Human Dignity in Bioethics and Law: Comparative Perspectives, edited by B. FeuilletLiger and K. Orfali, 167-177. Springer: Ius Gentium Series.

Crespo-Brauner, M.C., et al. 2018. Human Dignity in Brazilian Law: A Founding Principle of Laws and Court Judgements. In The Reality of Human Dignity in Bioethics and Law: Comparative Perspectives, edited by B. Feuillet-Liger and K. Orfali, 181-190. Springer: Ius Gentium Series.
Dos Anjos, F. 1999. Bioéthique et Inegalités Sociales. Revue Theologiques 7(1) :19-34.

Domínguez Hidalgo, C. 2016.: Human body and its protection: the principles of the Chilean law. In Protecting the human body: legal and bioethical perspectives from around the world, edited by in B. Feuillet-Liger and K. Orfali, 341-348. Bruxelles: Bruylant,

Feuillet-Liger, B. and K. Orfali (eds). 2018. The Reality of Human Dignity in Bioethics and Law: Comparative Perspectives. Springer, Ius Gentium Series.

Garcia, L.F., M.S. Fernandes, J.D. Moreno, and J.R. Goldim. 2019. Mapping Bioethics in Latin America: History, Theoretical Models and Scientific Output. Journal of Bioethical Inquiry 16(3) 1-9. https://doi.org/10.1007/s11673-019-09903-7

Garrafa, V. \& D. Porto. 2003. Intervention bioethics: A proposal for peripheral countries in a context of power and injustice. Bioethics 17 (5-6): 399-416.

Guiderdoni, A. 2001. Les principes fondateurs de l'éthique en islam. Revue d'éthique et de théologie morale, Le Supplément $\mathrm{n} 2017$, juillet : 88 .

Hassan, A. 2018. The Reality of the Human Dignity Principle in the Framework of the Egyptian Legal System. In The Reality of Human Dignity in Bioethics and Law: Comparative Perspectives, edited by B. Feuillet-Liger and K. Orfali, 153166. Springer: Ius Gentium Series.

Ibrahim, A.H., N.N.A. Rahman, S.M. Saifudden, and M. Baharuddin. 2019. Maqasid al-Sharia Based Islamic Bioethics: A Comprehensive Approach. Journal of Bioethical Inquiry 16(3) 1-13. https://doi.org/10.1007/s11673-019-09902-8

Metz, T. 2012. An African theory of moral status: A relational alternative to individualism and holism. Ethical Theory and Moral Practice 15: 387-482.

Mills, C. 2010. Continental Philosophy and Bioethics. Journal of Bioethical Inquiry 7(2):145-148.

Myser, C.(ed) 2011, Bioethics around the Globe. Oxford University Press.

Obeidat, A. and P.A. Komerasoff. 2019. The struggle for clinical ethics in Jordanian Hospitals. Journal of Bioethical Inquiry 16(3). https://doi.org/10.1007/s11673-019-09928-y

Padela, A.I. 2019. Using the Maqāșid al-Sharī ah to Furnish an Islamic Bioethics: Conceptual and Practical Issues, Journal of Bioethical Inquiry 16(3).

Schramm, F.R. 2008. Bioetica da protecao: Ferramenta valida para enfrentar problemes morais na era da globalizacao [Bioethics of protection: valid tool to face moral problems in the global era]. Revista Bioetica 16(1): 11-23.

Publisher's Note Springer Nature remains neutral with regard to jurisdictional claims in published maps and institutional affiliations. 